\title{
EXPERIMENTAL EVALUATION OF ALTERNATIVE MIX WATER FOR CONCRETE: CASE STUDY OF SEAWATER AND LABORATORY BRINE
}

\author{
O. U. Orie ${ }^{1^{*}}$ and A. M. Ojaruega ${ }^{2}$ \\ 1, 2 Civil Engineering Department, University of Benin, Benin City, Edo State. NigERIA \\ Email addresses:1 ogheneale@yahoo.com, ${ }^{2}$ oakpovona@yahoo.com
}

\begin{abstract}
This paper presents a comparison of seawater and laboratory brine on concrete using experimental methods. The seawater employed was obtained from Escravos in the coast of Atlantic Ocean in Nigeria. A concrete mix of 1:2:4and water/cement ratio of 0.6 was adopted. The cube samples measured $150 \mathrm{~mm} \times 150 \mathrm{~mm} \times 150 \mathrm{~mm}$. The samples were cured in potable water for a period of 7, 14, 21 and 28 days at $24^{\circ}$ C.The seawater and laboratory simulated saltwater contained an equal amount of salt ion concentration. The laboratory saltwater was prepared with an analytical grade sodium chloride salt. The concrete cubes cast with potable water had a 28 days compressive strength of $33.48 \mathrm{~N} / \mathrm{mm}^{2}$, concrete cubes cast with the seawater had a compressive strength of $31.04 \mathrm{~N} / \mathrm{mm}^{2}$, while the laboratory brined concrete cubes had a compressive strength of $25.26 \mathrm{~N} / \mathrm{mm}^{2}$. The results showed that the laboratory prepared salt water samples had the least compressive strength. Compared with the control samples, there was a strength reduction of $7.29 \%$ and $24.55 \%$ in the compressive strength of the seawater and laboratory saltwater samples respectively. Comparing the concrete cubes made with seawater with that of laboratory brined samples revealed a reduction of $18.62 \%$ in compressive strength of the laboratory brined concrete. Seawater therefore has a lesser reducing effect on the compressive strength of concrete than brine. Seawater is currently in use for mixing structural concrete in the Niger Delta region of Nigeria where portable water is not easily available.
\end{abstract}

Keywords: concrete, construction, seawater, simulated saltwater and compressive strength.

\section{INTRODUCTION}

Concrete is a composite construction material made up of water, cement aggregates -fine and coarse and sometimes extra materials called admixtures [1]. Generally concrete finds its use in virtually all civil engineering works. Concrete is the most widely used material in the world next to water [2].The effect of seawater on concrete was first discussed in 1840 ,since then the volume of literature on the subject has considerably increased [3].The water in concrete initiates the chemical process called hydration which results in the hardening of cement. Water and cement form the paste which acts as the binder in concrete. It has been shown that the quality of the water used in mixing and curing of cement products such as concrete, plays an important role in the mechanical properties of the product [4].Concrete cast with fresh water has been reported [5] to have compressive and flexural strengths greater than those cast with salt water. The work concluded that the chloride and sulphate in salt water reduced the strength of concrete by approximately $8 \%$ when used in mixing concrete [5].

The report on a study of the suitability of river water for curing on the compressive strength of structural concrete when it is mixed with both fresh water and saltwater and also cured with saltwater as well as freshwater showed that the concrete specimen made by using both fresh and river water and exposed to river water environment, showed changes in colour which was between light and dark grey [6]. The study also showed that salt water used in mixing the concrete ultimately affected the gain in strength of the concrete by about $10 \%$. The different aspects of deterioration of slag concrete was examined by [7], using both plain and river water. The results showed that slag concrete gave lower strength deterioration for a longer curing period compared to the concrete made from OPC. The work concluded that slag can be 
used in mixing cement concrete to combat deterioration in coastal or marine environments [7]. The durability of concrete structures exposed to marine environment depends mainly on the ability of concrete to resist chloride ingress [8]. A decline in the compressive strength of concrete cast and cured with seawater was observed when the effect of salt water from Seme River in Badagri on the compressive strength of concrete was examined [9]. However, saltwater has been shown to hasten hydration of concrete and increase its strength at maturity [10]. Glass fiber reduces rate of deterioration of concrete by chloride ions [11].The chemical process involving saltwater and concrete in contact with it has been explained [12]. The reaction of concrete and the surrounding saltwater result in the formation of efflorescence on the concrete surface. This efflorescence can be minimized by reducing the soluble salts in cement, and reducing the contact of concrete and river water [12]. The work concludes that efflorescence is more of an aesthetic defect and has little or no effect on the concrete structural properties and can be minimized by reducing the cyclic welting and drying of river water on concrete to avoid the crystallization of sulphate salts. Cement content is not a factor in terms of protecting concrete against saltwater effects [3] but ambient pressure has accelerated effects on the deterioration of concrete in deep river water environment [13] also, water flow accelerates the deterioration of concrete and that the combined effects of salt water and water flow are more severe and cause rapid deterioration [14]. There has been a recommendation that a rich mix other than 1:3:6 and 1:3:5 be strictly enforced on construction sites for concrete under saline attack [15]. A study [16] showed that for long-time durability of concrete exposed to seawater, a reduced permeability and reduced alkalinity of concrete appear to be as important as low $\mathrm{Ca} . \mathrm{Al}_{2} \mathrm{O}_{3}$ content of cement. It has also been shown that there was no reduction in the compressive strength of concrete when cast and cured with salty water [17]. An investigation of the effects of ocean salts on the compressive strength of concrete reported that, the compressive strength of concrete is increased by the presence of sodium chloride or ocean salts in the mixing water. The strength was found to increase with increasing salinity even up to $7 \%$ by weight of water [18]. This work evaluates the effect of seawater on some mechanical properties of concrete in the laboratory.

\section{MATERIALS AND METHODS}

The seawater employed was obtained from Escravos River in Nigeria and the portable water from the public water supply system. The Adsorption photospectrometer was used to determine the sodium, calcium, aluminum, Nitrate, Nitrite, Hardness, and Alkalinity concentrations of both water samples. A chloride meter was also used to determine their chloride concentration. Laboratory saltwater or brine was prepared using the portable water. The difference in the chloride content of both water samples was taken, and the salt content of the laboratory water was simulated to give an equal chloride concentration using an analytical grade sodium chloride salt.

The coarse aggregate used was granite with an average size of $12 \mathrm{~mm}$. The fine aggregate was river sand. The cement used was 42.5 grades Ordinary Portland Cement (OPC). Preliminary tests such as particle size distribution conforming to BS 8121(1975) was carried out on both aggregates. Water/ cement ratio $(\mathrm{w} / \mathrm{c})$ of 0.6 was used for the 1:2:4 concrete mix Initial and final setting times of the cement were determined by penetration test to BS 12:1996. Slump test was used to measure workability of the concrete. The concrete cube samples measured $150 \mathrm{~mm} \times 150 \mathrm{~mm} \times 150 \mathrm{~mm}$. They were cured in a laboratory at $24^{\circ} \mathrm{C}$ for $7,14,21$ and 28days at which age the various samples were tested. The compressive strength test was conducted and conforming to BS 1881- 108; 116 (1983). The cube samples were subjected to compressive stress using the compression testing machine. The cubes were loaded until failure was initiated by crushing. The compressive strength $\sigma$, was obtained using,

$$
\sigma=\frac{P_{\max }}{A_{0}}
$$

where, $P_{\max }$ is the crushing load and $A_{o}$ is the cross sectional area of cube.

\section{RESULTS AND DISCUSSION}

The grading curves of particle size distribution of the coarse and fine aggregates are shown in Figure 1. The figure reveals that the coarse aggregates is well graded and contained particles of $20 \mathrm{~mm}$ average size. The Figure also reveals that the fine aggregates belonged to zone 5 of the AASHTO classification. The results obtained from the workability test carried out on all three sets of concrete pastes are presented in Table 3. This table indicates that all the three mixes were very workable, with the laboratory salt water concrete (LSWC) having a slump value of $50 \mathrm{~mm}$ 
showing that it was the most workable. This is followed by the fresh water concrete (FWC) having a slump of $40 \mathrm{~mm}$, while the seawater concrete (SWC) was the least workable with a slump of $35 \mathrm{~mm}$. This result shows that workability can be affected by the hardness in seawater. The result for the setting time for the three cement pastes are presented in Table 4and it reveals that the cement paste made from portable water had an initial setting time of 1hour 58minutes and a final setting time of 3hours 35 minutes, the seawater cement paste had an initial setting time of 1 hour 43 minutes and a final setting time of 2 hours 27 minutes, while the laboratory simulated saltwater cement paste had an initial setting time of I hour 48minutes and a final setting time of 3hours 9 minutes.The result indicates that salt water decreases setting time of cement paste (initial and final) when compared with potable water.

Table 1.Chemical composition of Escravos Sea water

\begin{tabular}{lccc}
\hline $\begin{array}{l}\text { Chemical } \\
\text { Element/Compo } \\
\text { und }\end{array}$ & $\begin{array}{c}\text { Concentrat } \\
\text { ion }(\mathrm{mg} / \mathrm{l})\end{array}$ & $\begin{array}{c}\text { Chemical } \\
\text { Element/Compo } \\
\text { und }\end{array}$ & $\begin{array}{c}\text { Concentrat } \\
\text { ion }(\mathrm{mg} / \mathrm{l})\end{array}$ \\
\hline Sodium $(\mathrm{Na})$ & 60.3 & Nitrate & 10 \\
Calcium $(\mathrm{Ca})$ & 21.8 & Nitrite & 0.00 \\
Aluminum $(\mathrm{Al})$ & 0.001 & Hardness & 249 \\
Chloride $(\mathrm{Cl})$ & 630.2 & Alkalinity & 267 \\
Sulphate $\left(\mathrm{SO}_{4}\right)$ & 15.68 & Others & 0 \\
\hline
\end{tabular}

Table 2.Chemical composition of portable water

\begin{tabular}{cc}
\hline Compound & Concentration $(\mathrm{mg} / \mathrm{l})$ \\
\hline Sodium & 5.99 \\
Calcium & 0.63 \\
Chloride & 3.54 \\
Nitrate & 0.00
\end{tabular}

Table3. Workability of concrete

\begin{tabular}{cc}
\hline Type of mix water & Slump $(\mathrm{mm})$ \\
\hline Potable water concrete & 40 \\
Seawater concrete & 35 \\
Laboratory saltwater concrete & 50 \\
\hline
\end{tabular}

\begin{tabular}{lccc}
\multicolumn{4}{c}{ Table4. Consistency of cement paste } \\
\hline Property & $\begin{array}{c}\text { Potable } \\
\text { water } \\
\text { concrete }\end{array}$ & $\begin{array}{c}\text { Seawater } \\
\text { concrete }\end{array}$ & $\begin{array}{c}\text { Laboratory } \\
\text { saltwater } \\
\text { concrete }\end{array}$ \\
\hline Consistency $(\mathrm{mm})$ & 5 & 6 & 5 \\
Initial setting time $(\mathrm{min})$ & 118 & 103 & 108 \\
Final setting time $(\mathrm{min})$ & 185 & 147 & 189 \\
Amount of water $(\mathrm{ml})$ & 113 & 115 & 116 \\
\hline
\end{tabular}

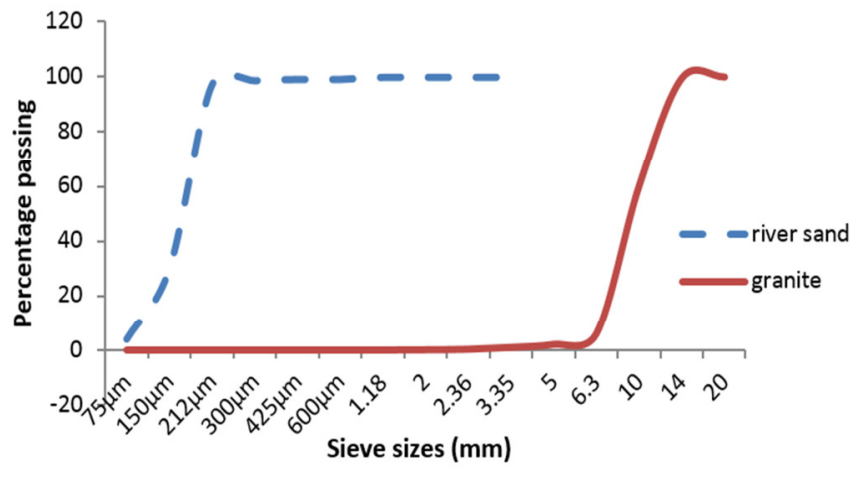

Figure 1. Particle size distribution of aggregates

Table 1 and Table 2 show that there is no nitrate in both seawater and potable water. The tables show a higher concentration of Sodium and Chloride of 60.3 $\mathrm{mg} / \mathrm{l}$ and $630.2 \mathrm{mg} / \mathrm{l}$ respectively in seawater, compared with $5.99 \mathrm{mg} / \mathrm{l}$ and $3.54 \mathrm{mg} / \mathrm{l}$ respectively in potable water. The results for the compressive strength for concrete samples prepared with the three different water samples are presented in Figure 2. The Figure 2 shows that concrete made with portable water (PWC) had the highest 7days compressive strength of $27.63 \mathrm{~N} / \mathrm{mm}^{2}$ but the 14 days compressive strength was lower than its 7 days compressive strength with a value of $22.21 \mathrm{~N} / \mathrm{mm}^{2}$. The rapid gain in 7 days strength could be attributed to the calcium trisilicate $\left(\mathrm{C}_{3} \mathrm{~S}\right)$. There was a slight increase in the 21days compressive strength for the PWC which had a compressive strength of $24.74 \mathrm{~N} / \mathrm{mm}^{2}$. The figure showed that PWC had a 28days compressive strength of $33.48 \mathrm{~N} / \mathrm{mm}^{2}$.It is seen from Figure 2 that the seawater and laboratory brine generally resulted in lower compressive strength concrete at early ages but the difference becomes minimal at full maturity. The concrete prepared with seawater produced compressive strength of comparable values to that prepared with potable water.

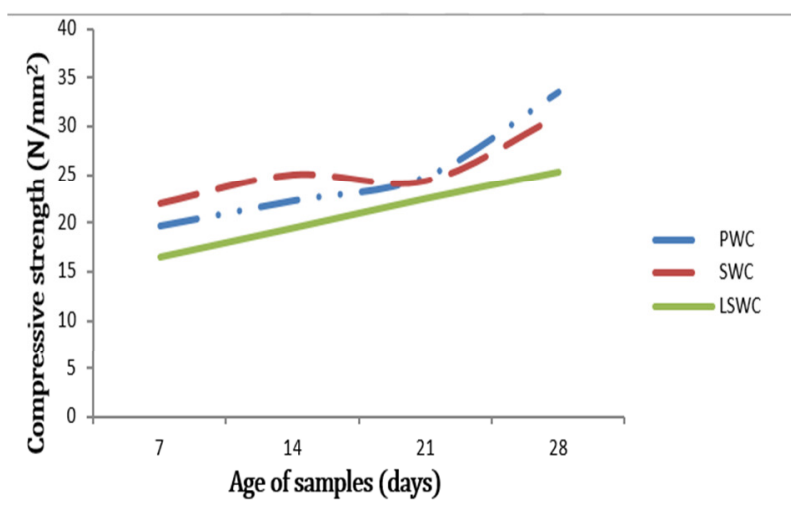

Figure 2: Relationship between compressive strength and curing age of concrete 
Figure 2 also shows that the concrete cubes cast with the Escravos sea water (SWC) had a 7 days compressive strength of $21.93 \mathrm{~N} / \mathrm{mm}^{2}$, which was less than that of PWC which was $19.64 \mathrm{~N} / \mathrm{mm}^{2}$. The cube samples showed a uniform SWC concrete increase in compressive strength with age. It had a 14days compressive strength of $24.96 \mathrm{~N} / \mathrm{mm}^{2}$ and a 21days compressive strength of $28.29 \mathrm{~N} / \mathrm{mm}^{2}$. The 28days compressive strength of SWC is $31.04 \mathrm{~N} / \mathrm{mm}^{2}$ which was lower than that of the control mix which was $33.30 \mathrm{~N} / \mathrm{mm}^{2}$. This is reduction of $7.29 \%$. This figure reveals that the laboratory simulated salt water concrete (LSWC) gave the least compressive strength at 7, 14, 21 and 28days of curing. The LSWC had a 7 days compressive strength of $16.45 \mathrm{~N} / \mathrm{mm}^{2}$, a 14 days compressive strength of $19.41 \mathrm{~N} / \mathrm{mm}^{2}$, a 21 days compressive strength of $22.44 \mathrm{~N} / \mathrm{mm}^{2}$ and a 28days compressive strength of $25.26 \mathrm{~N} / \mathrm{mm}^{2}$. The reduction in compressive strength of about $24 \%$ below PWC indicated by the laboratory prepared saltwater can be attributed to hardness and alkalinity in high concentration present in the water that was used in mixing the concrete. However, it can be observed from Figure 2 that the samples gained strength with age which is a common phenomenon with concrete.

Although both SWC and LSWC samples contained an equal amount of salt concentration the reduction in strength indicated was not the same. The seawater contained other significant properties and compounds in high concentrations which are believed to be responsible for the difference in strength for both samples of salt water concrete. These properties included hardness which was present in the seawater in excess of about $249 \mathrm{mg} / \mathrm{l}$, alkalinity in excess of about $267 \mathrm{mg} /$ land Calcium $21.8 \mathrm{mg} / \mathrm{l}$ which have affinity to cement constituents (see Table 1). Hence, it is reasoned that there are reactions between these compounds and the cement that countered the reduction in strength effect caused by the concentration of salt in the seawater. Table 1 show that seawater contains $15.68 \mathrm{mg} / \mathrm{l}$ of the sulphate radical. This may combine with hydrogen in water to form acid which in turn release hydrogen ions which literature [21] has shown to reduce the compressive strength of concrete.

\section{CONCLUSION}

The chemical analysis shows a distinction between seawater and potable water. The use of seawater and laboratory simulated saltwater or brine and their effect on concrete have been evaluated experimentally with a view to incorporating them as alternatives to portable water for concrete mixing in construction works. This evaluation has shown that seawater causes an insignificant reduction of $7.29 \%$ in the compressive strength of concrete compared with portable water at 28 days. Its effect on the workability of concrete is also minimal as concrete containing seawater is very workable. Brine produces concrete with much lower compressive strength than seawater and hence potable water. The relatively higher compressive strength exhibited by seawater in concrete when compared with brine may be attributable to compounds like calcium, and other properties such as hardness and alkalinity, in high concentrations present in seawater. These compounds have high affinity to Ordinary Portland Cement (OPC). However, the long term effect after 28days has not been tested.

\section{REFERENCES}

[1] Orie, 0. U. Five Component Concrete Mix Optimization Using Scheffe's Theory - a Case Study of Mound Soil as a Mix Component, Ph.D. Thesis, University of Benin, Benin City, Nigeria, 2008.

[2] Bhanu, S. P. and Lakshmi, V. "A Study on Fly Ash Concrete in Marine Environment", International Journal of Innovative Research Science, Engineering and Technology,Vol.3, Number 5, 2014, pp 1239512401.

[3] Zaher, K. and Samir, S."Effect of Gaza Seawater on Concrete Strength for Different Exposures", Journal of the Islamic University of Gaza, Vol. 11, Number 2, 2003, pp156-172.

[4] Orie, 0. U. "Water Quality and the Compressive Strength of Concrete -a Case Study of Hydrogen Point Concentration", Pakistan Journal of Science and Industrial Research, Vol. 55, 2012, Number 3, pp 169-171.

[5] Mbadike, E. M. and Elinwa, A. U. "Effect of Salt Water in the production of Concrete", Nigerian Journal of Technology, Vol. 30, Number 2, 2011, pp105-109.

[6] Moinul, I., Saiful, I., Amin, A. and Mydul, I. "Suitability of Sea Water on Curing and Compressive Strength of Structural Concrete", Journal of Civil Engineering, Vol. 40, Number 1,2012, pp 37-45.

[7] Moinul, I.,Saiful, I., Bipul, C. M. and Mohammad, R.I. "Strength Behaviour of Concrete Using Slag with Cement in River Water Environment" ,Journal of Civil Engineering, Vol. 38, Number 2,2010, pp 129-140.

[8] Costa, A. and Appleton, J. "Chloride Penetration into Concrete in Marine Environment. Part 1-main Parameters Affecting Chloride Penetration", 
Maternal and Structures, Vol. 32, Number 4, 1999, pp 252-259.

[9] Eyieta, 0. M. Effect of Salt Water on Concrete Compressive Strength Using Various Water Cement Ratio, B. Eng. Thesis, University of Benin, Benin City, Nigeria, 2014.

[10] Nami, G. Effect of Salt Water on the Engineering Properties of Concrete, M. Eng. Thesis, University of Benin, Benin City, Nigeria, 2012.

[11] Eather, T. D. and Ali, J. H."Effect of $\mathrm{NaCl}$ on the Mechanical Properties of Structural Foamed Concrete Reinforced with Fiber", Journal of Zhejiang University. Vol. 1, Number 3, 2008, pp 4-9.

[12] Mather, B. Effect of sea Water on Concrete, U.S. Army Engineer waterways Experiment Station, Corps of Engineers, Mississippi, 1972.

[13] Kaushik, S. K., Islam, S. M and Islam, M."Physical and Mechanical Behavior of Concrete in Sea Water Under Hydrostatic Pressure" Journal of the Institution of Engineers, Vol. 66, 2005, pp 46- 52.

[14] Behnam, A. and Saleh, S. T. "Combined Effects of Saltwater and Water Flow on Deterioration of Concrete Under Freeze-thaw Cycles", Journal of Cold Regions Engineering, Vol. 25, Number 2,2011,pp145161.

[15] Akinsola, O. E., Fatokun, A. O. and Ogunsanmi, O. E. "Investigation of Salinity Effect on Compressive Strength of Reinforced Concrete", Journal of
Sustainable Development, Vol. 5, Number 6,2012, pp 74-82.

[16] Mehta, P. K. and Haynes, H. H. "Durability of Concrete in Seawater", Journal of the Structural Division, Vol. 101, 1975, pp 1679-1686.

[17] Tiwari. P, Chandak, R. and Yadav, R. K. "Effect of Salt Water on Compressive Strength of Concrete", International Journal of Engineering Research and Applications, Vol. 4, Number 5, 2014, pp 38-42.

[18] Taylor, M. A. and Kuwairi, A. "Effects of Ocean salts on the Compressive Strength of Concrete", Cement and Concrete Research, Vol. 8, Number 4, 1978, pp 491-500.

[19] British Standards Institution, BS 812: Part 1. Methods for Determination of Physical Properties of Aggregate, British Standards House, London, 1975.

[20] British Standards Institution, BS 812. Specification for Portland Cement, British Standards House, London, 1996.

[21] British Standards Institution, BS: 1881 part 108; 116.Methods for Making test cubes from fresh Concrete, British Standards House, London, 1983.

[22] Orie ,O. U. "Water Quality and the Compressive Strength of Concrete -A Case Study of Hydrogen Point Concentration", Pakistan Journal of Scientific and Industrial Research, Vol. 55, Number 3, 2012, pp 169-171. 